\title{
THỰC TRẠNG VÀ GIẢI PHÁP CHO VẤN ĐỂ THẤT NGHIỆP Ở VIỆT NAM TRONG THỜI KÌ DỊCH BỆNH COVID-19
}

\author{
Phạm Minh Thu, Hoàng Thị Bích Thủy, \\ Trịnh Minh Thúy, Nguyễn Phúc Thư, Nguyễn Thị Thương
}

Đại học Quốc gia Hà Nội

Ngày 15 tháng 2 năm 2022

Preprint DOI: 10.31219/osf.io/mv6ga 
Thất nghiệp vẫn luôn là vấn đề quan trọng đòi hỏi được giải quyết hợp lý và ta không thể nhìn nhận nó ở một phạm vi nhất định mà phải bao quát, khai thác vấn đề sâu hơn. Tiếp nối các phân tích rõ ràng về khái niệm, thực trạng và những số liệu thống kê chi tiết nêu trên. Sau đây chúng em xin được chuyển sang phần 2 của bài và tiến hành thảo luận theo 4 ý: Nguyên nhân dẫn đến thất nghiệp trong bối cảnh tình hình dịch COVID-19, Lợi ích, Hậu quả gây ra và Những giải pháp khắc phục. Từ đó đưa ra kết luận, khái quát lại vấn đề.

\section{I.Nguyên nhân dẫn đến thất nghiệp trong bối cảnh tình hình dịch COVID-19}

Được phát hiện ra từ thành phố Vũ Hán vào cuối năm 2019, COVID-19 đang là dịch bệnh nguy hiểm đến sức khỏe, thậm chí là tính mạng con người, chúng lây lan qua đường hô hấp vì thế mà chúng ta phải hạn chế tiếp xúc với nhau và áp dụng giãn cách xã hội (La, 2020). Điều này khiến hầu hết các công việc phải dừng lại. Tình hình dịch bệnh kéo dài đã làm biết bao người lao động mất việc làm, thậm chí nhiều công ty, doanh nghiệp phải phá sản vì không thể cầm cự.

- Lưu thông vận chuyển hàng hóa, nguyên vật liệu đến các nhà máy khó khăn nên việc sản xuất đình trệ, không cần đến nhiều nhân công như trước.

- Nhu cầu mua hàng của nhân dân giảm sút, sản phẩm làm ra nhưng không tiêu thụ được dẫn đến hiện tượng dư cung ở những ngành hàng nhất định.

- Lực lượng lao động phân bố không đồng đều (chủ yếu tập trung ở đồng bằng, nơi có nhiều khu công nghiệp)

- Tình trạng thất nghiệp gia tăng do sự suy giảm của nền kinh tế toàn cầu:

Dịch bệnh hoành hành khiến nền kinh tế toàn cầu suy giảm, nhiều xí nghiệp nhà máy buộc phải thu hẹp việc sản xuất, thậm chí là đóng cửa, phá sản. Chính vì vậy mà các doanh nghiệp phải cắt giảm nhân công dẫn đến việc người lao động mất việc làm. Việc đi xuất khẩu lao động ở nước ngoài gặp nhiều khó khăn và trở ngại hơn lúc trước trong khi việc làm trong nước không đủ.

Mức thu nhập của người dân giảm.

$\Rightarrow$ Cầu giảm làm ảnh hưởng tới cung.

$\Rightarrow$ Các nhà máy không cần nhiều nhân công để tạo ra sản phẩm.

Kinh tế Việt Nam còn phụ thuộc khá nhiều vào đầu tư và xuất khẩu nên khi kinh tế toàn cầu bị suy giảm do đại dịch thì nền kinh tế Việt Nam cũng bị ảnh hưởng rất lớn. => Nạn thất nghiệp tăng cao

\section{II.Loi ích}

Nếu thất nghiệp trong một khoảng thời gian ngắn thì nó cũng đem lại một số lợi ích đáng xem xét:

- Người lao động sẽ tìm được việc làm theo ý thích và có thể phù hợp hơn về nguyện vọng, năng lực.

- Mặt tích cực đối với xã hội: khiến công tác phân bổ nguồn lực được hiệu quả hơn và góp phần làm tăng tổng sản lượng của nền kinh tế trong dài hạn.

- Đem lại khoảng thời gian nghỉ ngơi và phục hồi sức khỏe cho nguồn nhân công. 
- Thất nghiệp để con người chậm lại, dành thời gian cho việc học hành và trau dồi thêm kỹ năng cần thiết.

- Tạo nên sự cạnh tranh và tăng hiệu quả nhất định.

\section{III.Hâu quả}

\section{Về mặt vi mô:}

- Thất nghiệp dẫn đến hậu quả cho cá nhân bên cạnh những hệ lụy cho xã hội, gây ra nhiều thiệt thòi cho các cá nhân. Nguồn thu, chi tiêu cho cá nhân, cho gia đình, và xã hội giảm đáng kể. Khi nguồn thu nhập từ các gia đình bị giảm sút sẽ gây ra các hậu quả nặng nề về kinh tế, xã hội.

- Thất nghiệp ảnh hưởng đến thu nhập và đời sống của người lao động, trật tự xã hội: Việc thất nghiệp dễ dẫn đến việc vợ chồng mâu thuẫn, cãi cọ, hòa khí trong gia đình bị tác động xấu. Khi thiếu thốn về kinh tế, con người thường thiếu sự tự tin, dễ nổi nóng, cáu giận, nhất là ở những người đàn ông khiến nạn bạo hành tiếp diễn tiêu cực. Thất nghiệp mang đến gánh nặng về kinh tế gia đình và con người có xu hướng làm những công việc vi phạm pháp luật, trái đạo đức như trộm cắp, mại dâm, buôn lậu... để mưu sinh, trang trải cuộc sống. Các nguồn thu nhập để chi trả cho học hành của con cái sẽ bị ảnh hưởng, thậm chí là mất đi. Nếu tình trạng này kéo dài theo chiều hướng tiêu cực thì những đứa trẻ sẽ không được đến trường học hành tử tế, lêu lổng, sa ngã... tiếp tục gây nên những hệ lụy khó lường cho xã hội.

\section{Đối với nền kinh tế}

- Thất nghiệp tạo ra sự áp đặt chi phí cơ hội cho nền kinh tế. Có công nhân thất nghiệp tức là nền kinh tế chưa sử dụng hiệu quả tất cả các nguồn lực của nó. Nền kinh tế sẽ khó tạo ra nhiều hàng hóa và dịch vụ tối ưu.

- Thất nghiệp cũng có nghĩa là doanh thu từ thuế của chính phủ sẽ giảm sút so với mức có thể. Khi con người mất việc, thu nhập sẽ ít đi và họ có xu hướng chi tiêu ít lại để tiết kiệm rồi kết quả là nguồn thu từ thuế cũng giảm theo. Thu nhập và lợi nhuận của các doanh nghiệp giảm đi. Do đó, doanh thu từ thuế thu nhập và thuế doanh nghiệp không ổn định và khó tránh khỏi tình trạng thâm hụt.

- Ngoài việc giảm doanh thu từ thuế, thất nghiệp cũng gây áp lực lên chi tiêu công của chính phủ. Nguồn chi cho trợ cấp thất nghiệp sẽ tự động tăng lên khi người lao động thất nghiệp nhiều. Nếu người thất nghiệp có tình trạng sức khỏe xấu, chính phủ có thể phải chi nhiều hơn cho việc chăm sóc y tế.

- Nguy cơ thất nghiệp gia tăng có thể dẫn đến thực trạng tội phạm gia tăng, vì một số người thất nghiệp có thể dùng đến các hoạt động phạm tội để có thu nhập cao hơn. Nếu những hành vi phạm pháp gia tăng, chính phủ sẽ phải chi nhiều hơn để giải quyết vấn đề và đảm bảo an ninh, an toàn cho xã hội.

- Thất nghiệp tăng lên đồng nghĩa nền kinh tế đang đến với ngưỡng cửa của sự suy thoái. Suy thoái do tổng thu nhập thực tế thấp hơn tiềm năng; suy thoái do thiếu vốn đầu tư ( ngân sách nhà nước bị thu hẹp do thất thu thuế lại phải trích ra hỗ trợ cho những người lao động mất việc làm...) Nạn thất nghiệp tăng lên cũng là một trong các nguyên nhân đẩy nền kinh tế đến với "bờ vực" của vấn đề lạm phát.

$\Rightarrow$ Thất nghiệp khiến các dây chuyền sản xuất ít, chậm trễ hơn. Giảm năng suất, tính hiệu quả của các hoạt động sản xuất hàng hóa theo quy mô. 
- Theo dự kiến, nền kinh tế Việt Nam tăng trưởng chậm hơn do sự bùng phát trở lại của đại dịch COVID-19, dịch bệnh gây ra sự gián đoạn nguồn lao động, giảm sản lượng của công nghiệp và khiến chuỗi giá trị nông nghiệp đứt gãy (dựa trên báo cáo từ Ngân hàng Phát triển Châu Á (ADB) công bố )

- Thất nghiệp dẫn đến nhu cầu xã hội giảm, ảnh hưởng tới sức mua. Hàng hóa và dịch vụ sản xuất ra lại không có người tiêu thụ, sử dụng, cơ hội kinh doanh vốn khó khăn nay lại càng ít ỏi, chất lượng sản phẩm và giá cả tụt giảm, ảnh hưởng không nhỏ và cơ hội đầu tư cũng ít đi. Lãi ròng của các doanh nghiệp bị giảm, các khoản thu không ổn định.

$\Rightarrow \mathrm{CPI}$ (chỉ số giá tiêu dùng) tăng thấp nhất trong vòng 5 năm qua.

\section{IV.Giải pháp}

Thất nghiệp là vấn đề lớn liên quan đến sinh kế người dân và hệ lụy xã hội, tăng trưởng kinh tế của đất nước. Cách tiếp cận chung cho vấn đề này là sử dụng hệ sinh thái giải pháp. Trong đó sử dụng hệ xử lý thông tin 3D (Vuong, Q.H., 2022), nhà nước cần tập trung kiểm soát tốt thông tin, truyền thông hiệu quả (Vuong \& Napier, 2014), đầu tư mạnh cho khoa học công nghệ (Vuong, 2018), hợp tác với chuyên gia và các bên liên quan để có các giải pháp sáng tạo. Cách tiếp cận cụ thể, tác động từ đại dịch COVID-19 đã làm cho người dân lao đao, gặp nhiều khó khăn hơn trong việc tham gia vào thị trường lao động và đóng góp cho chuỗi sản xuất hàng hóa và dịch vụ.

\section{Về phía nhà nước:}

- Tăng cường sử dụng các nguồn vốn đầu tư (chủ yếu lấy từ dự trữ quốc gia, vay thêm nước ngoài) để đẩy nhanh tiến độ xây dựng, cải tạo cơ sở hạ tầng, làm thuỷ lợi, giao thông, thủy điện...

- Tạo công ăn việc làm mới cho lao động mất việc ở khu vực sản xuất kinh doanh, nới lỏng các chính sách tài chính, cải cách thủ tục hành chính, tránh lằng nhằng, lòng vòng nhằm thu hút vốn đầu tư từ nước ngoài.

- Tạo dựng quỹ hỗ trợ những công dân có nhu cầu đi xuất khẩu lao động.

- Khuyến khích, động viên phát triển các doanh nghiệp vừa và nhỏ, cung cấp cho họ nguồn vay hợp lý để trang bị, cải tiến máy móc phục vụ mở rộng, đẩy mạnh sản xuất.

- Sắp xếp lại theo đúng trật tự và nâng cao hiệu quả của hệ thống dịch vụ việc làm. Xã hội hoá đồng thời nâng cao chất lượng đào tạo dạy nghề cho công nhân.

- Khuyến khích sử dụng nguồn lao động là nữ, người tàn tật. Quan tâm hỗ trợ các cơ sở sản xuất của người khuyết tật và thương binh. Đầu tư phát triển ở những vùng trung du, miền núi, các vùng quê còn nhiều khó khăn để phân bổ nguồn nhân công.

- Hỗ trợ vận động tiêm vaccine phòng dịch cho người dân để đạt được miễn dịch cộng đồng.

- Sử dụng hợp lý, kịp thời chính sách bảo hiểm thất nghiệp, bảo hiểm xã hội nhằm hỗ trợ một phần kinh phí cho lao động thuộc diện chính sách ưu đãi, đối tượng yếu thế trong xã hội.

- Tập chung phần vổn tín dụng từ quỹ quốc gia về việc làm với lãi xuất ưu đãi phù hợp.

- Thực hiện chính sách gia hạn hoặc miễn giảm thuế, phí, tiền thuê mặt bằng, giảm giá điện, nước, xăng, cước viễn thông, gas,... 
- Tăng cường công tác tuyên truyền vận động nhằm nâng cao nhận thức của công nhân, người lao động để họ thấy rõ việc học tập nâng cao trình độ, kỹ năng nghề nghiệp vừa là quyền lợi, vừa là yêu cầu để đảm bảo việc làm, nâng cao thu nhập, nâng cao năng suất lao động, bảo đảm chất lượng sản phẩm, góp phần nâng cao năng lực cạnh tranh, phát triển doanh nghiệp, phát triển kinh tế - xã hội

- Với tình trạng chất lượng nguồn nhân lực còn thấp, Nhà nước nên tổ chức các chương trình đào tạo lại để nâng cao chuyên môn và kỹ thuật, đáp ứng nhu cầu kinh tế ngày càng phát triển sâu rộng

- Trong đại dịch Covid-19 đang hoành hành tại nước ta, nhiều người lao động và doanh nghiệp bị ảnh hưởng nặng nề do đó rất cần có sự giúp đỡ từ phía Chính phủ. Điều đầu tiên Chính phủ có thể giúp để giảm bớt gánh nặng cho doanh nghiệp và người lao động đó là miễn giảm thuế thu nhập.

- Sự giảm sút của tổng cầu là nguyên nhân gây ra khủng hoảng kinh tế, doanh nghiệp phải thu hẹp sản xuất và công nhân bị thất nghiệp. Vì vậy, cần thiết phải có sự can thiệp của Nhà nước nhằm nâng cao tổng cầu trong nền kinh tế, hay như hiện nay chúng ta gọi là phải kích cầu tiêu dùng và cầu đầu tư.

\section{Về phía doanh nghiệp:}

- Ở những vùng có tình hình dịch căng thẳng, phức tạp doanh nghiệp có thể thực hiện phương án "3 tại chỗ": sản xuất, ngủ nghỉ và ăn ở ngay tại công ty. Nhưng vẫn phải thực hiện nghiêm chỉnh, đầy đủ các quy tắc phòng dịch, tránh lây lan mạnh hơn.

- Vận động kêu gọi người lao động trở lại doanh nghiệp làm việc trong giai đoạn bình thường mới bằng những chính sách phù hợp:

Lãnh đạo các doanh nghiệp, cơ sở sản xuất cần nhanh chóng hình thành phương án khả thi để khôi phục lại sản xuất, kinh doanh.

Cấp ủy, lãnh đạo các doanh nghiệp xây dựng các chính sách tốt để giữ chân người lao động, nhất là các vị trí cần kinh nghiệm dày dặn và tay nghề cao. Có thể giữ chân nhóm lao động ngoại tỉnh bằng cách cho họ được ưu tiên tiêm vaccine ngừa Covid-19, tạo điều kiện trong việc đi lại, nơi ở.

Quan tâm, phối hợp cùng thực hiện các chương trình, chính sách thu hút lớp lao động trẻ, năng động nhất là những sinh viên mới tốt nghiệp và chưa tìm được việc làm, sẵn sàng tuyển dụng họ vào công ty để đào tạo bài bản, thay thế dần các khâu đang bị thiếu hụt nguồn lao động.

\section{Đối với những người lao động:}

- Trong giai đoạn khó khăn này cần giữ vững tâm thế bình tĩnh và chủ động liên hệ trao đồi với chủ doanh nghiệp về những khó khăn, khúc mắc đang gặp phải, nhằm đưa những giải pháp xử lý kịp thời và phù hợp nhất.

- Phối hợp chặt chẽ với chủ doanh nghiệp và chính quyền địa phương để sớm được tiêm đủ 2 liều vaccine phòng ngừa Covid19. Bên cạnh đó, mỗi người lao động cần nâng cao ý thức về phòng, chống dịch trong điều kiện mới, trau dồi kỹ năng cần thiết, rèn luyện sức khỏe và cùng tích cực hợp tác với doanh nghiệp, tìm phương án tối ưu để có thể quay trở lại công ty làm việc sớm nhất.

- Người lao động tự nâng cao chuyên môn và kỹ thuật. Khi có điều kiện và cơ hội, bản thân người lao động nên chủ động học hỏi, tiếp thu và cập nhật những kiển thức mới để nâng cao chuyên môn và tay nghề của mình. Đó là cách giúp người lao 
động tăng cơ hội tìm kiếm việc làm và thăng tiến trong công việc, đồng thời thu nhập cá nhân cũng sẽ tăng lên.

- Người lao động nên tham gia bảo hiểm thất nghiệp để khi họ mất việc làm sẽ có một khoản tiền trang trải cho cuộc sống và có cơ hội tìm một công việc mới. Hơn nữa, bảo hiểm thất nghiệp còn hỗ trợ người lao động học nghề, đào tạo, bồi dưỡng, nâng cao trình độ kỹ năng nghề để duy trì việc làm (Điều 42 Luật việc làm 2013).

\section{Kết luận:}

Sự khủng hoảng bất đắc dĩ đến từ đại dịch COVID - 19 đã đặt ra nhiều thách thức mới về vấn đề đảm bảo an toàn trong việc làm. Dịch bệnh bất ngờ xuất hiện đã thay đổi hoàn toàn viễn cảnh của sự vận hành thông thường trong cấu trúc sản xuất và thương mại toàn cầu, ít nhất là trong ngắn hạn. Nhiều thị trường tiêu thụ lớn ở địa phương, trong nước và cả quốc tế bị đình trệ dẫn tới đứt gãy tạm thời trong các chuỗi cung ứng thiết yếu. Thị trường lao động trong thời COVID-19 được đánh giá sẽ có tác động sâu rộng đến kết quả thị trường lao động chung. Những quan ngại trước mắt về sức khỏe của nhân công và gia đình họ, virus và các cú sốc kinh tế tiếp theo sẽ tác động đến nguồn việc làm. Cung lao động đang giảm đi vì các biện pháp giãn cách xã hội, sự cản trở của bệnh tật và suy giảm các hoạt động kinh tế, buôn bán, trao đổi. Cho đến thời điểm hiện tại, dịch bệnh COVID-19 ở nước ta dù vẫn đang có những diễn biến rất phức tạp nhưng khi nhân dân cả nước đồng lòng chung tay chống dịch và nâng cao ý thức, trách nhiệm thì dịch bệnh sẽ tạm thời được kiểm soát và cuộc sống của người dân có thể trở lại bình thường. Hiện nay nhiều bệnh nhân dương tính với virus đã được điều trị, phục hồi sức khỏe và được xuất viện, trở lại cuộc sống bình thường chính là những tín hiệu đáng mừng, là "liều thuốc tinh thần" hữu hiệu an ủi, trấn an tâm lí người dân cả nước, giúp họ yên tâm lao động, sản xuất và học tập...

\section{TÀI LIỆU THAM KHẢO:}

La, V. P. et al. (2020). Policy response, social media and science journalism for the sustainability of the public health system amid the COVID-19 outbreak: The vietnam lessons. Sustainability (Switzerland), 12(7). https://doi.org/10.3390/su12072931

Vuong, Q.H., et al. (2022). Covid-19 vaccines production and societal immunization under the serendipity-mindsponge-3D knowledge management theory and conceptual framework.

Humanities \& Social Sciences Communications, 9, 22. Retrieved from: https://www.nature.com/articles/s41599-022-01034-6

Vuong, Q. H. (2018). The (ir)rational consideration of the cost of science in transition economies. Nature Human Behaviour, 2(1), 5. https://doi.org/10.1038/s41562-017-0281-4

Vuong, Q. H., \& Napier, N. K. (2014). Making creativity: the value of multiple filters in the innovation process. International Journal of Transitions and Innovation Systems, 3(4), 294327. https://doi.org/10.1504/ijtis.2014.068306

An Hạ. (n.d.). CPI tăng thấp nhất trong vòng 5 năm. Bộ Công Thương Việt Nam. https://moit.gov.vn/tin-tuc/thi-truong-trong-nuoc/cpi-tang-thap-nhat-trong-vong-5-nam.html

Bộ Y Tế. (2022). CỔNG THÔNG TIN CỦA BỘ Y TÉ VỂ ĐAI DICH COVID-19. Bộ Y Tế. https://covid19.gov.vn/

Cai, C. thông tin điện tử tỉnh L. (2021). Kết quả chủ yếu của điều tra lao động việc làm năm 
2019. Cổng Thông Tin Điện Tử Tỉnh Lào Cai.

https://bqlkkt.laocai.gov.vn/1250/28226/47120/581632/tin-tong-hop/ket-qua-chu-yeu-cuadieu-tra-lao-dong-viec-lam-nam-2019

Hà Nam, K. T. (2021). Thất nghiệp, thiếu việc làm gia tăng. VOV. https://vov.vn/xa-hoi/thatnghiep-thieu-viec-lam-gia-tang-883069.vov

Hoàng, N. (2020, July 10). Đại dịch COVID-19 ảnh hưởng tiêu cực đến tình hình lao động, việc làm. Báo Điện Tử Chính Phủ. https://baochinhphu.vn/print/dai-dich-covid-19-anh-huongtieu-cuc-den-tinh-hinh-lao-dong-viec-lam-102275431.htm

Huỳnh, P. (2014). Thếnào là việc làm và thất nghiệp: Một số câu hỏi thường gặp. Tổ Chức Lao Động Quốc Tế.

http://www.ilo.org/hanoi/Informationresources/Publicinformation/newsitems/WCMS_3092 79/lang-vi/index.htm?fbclid=IwAR32iV1DUQDQ4J39W0wsmJAtLSW34w52NkwBLWL_Nut_Rf unptGY2a81gIU

Luật Quang Huy. (n.d.). Vấn đề thất nghiệp - Lý thuyết và thưc tiễn tại Việt Nam. Luật Quang Huy. https://www.luatquanghuy.edu.vn/blog/bai-tap-luat/luat-an-sinh-xa-hoi/van-de-thatnghiep-ly-thuyet-va-thuc-tien-tai-viet-nam/

Ngọc, N. (2021, August 18). Thất nghiệp là gì? Có bao nhiêu loại thất nghiệp trong kinh tế vĩ $m \hat{o}$ ? News.Timviec.Com.Vn. https://news.timviec.com.vn/that-nghiep-la-gi-cach-phan-loaiva-tac-dong-cua-no-den-nen-kinh-te-50061.html

Nhi, A. (2021). Tăng trưởng GDP cả năm 2021 dụ báo chỉ đạt 1,9\%? VnEconomy. https://vneconomy.vn/tang-truong-gdp-ca-nam-2021-du-bao-chi-dat-1-9.htm

TCTK, T. hình kinh tế-xã hội năm 2018. (2018). TÌNH HÌNH KINH TÉ- XÃ HỘI NĂM 2018. Trang Thông Tin Điện Tử Tổng Cục Dân Số-Kế Hoạch Hóa Gia Đình. http://gopfp.gov.vn/chi-tiet-an-pham/-/chi-tiet/tinh-hinh-kinh-te-xa-hoi-nam-2018-84103310.html\#: : :text=Tính chung cả năm 2018\%2C tỷ lệ thất nghiệp chung,thôn là $1 \% 2 \mathrm{C} 74 \% 25$.

Thanh, L. (2021). Vận động nguời lao động trở lại doanh nghiệp làm việc trong giai đoạn bình thuờng mới. Trang Tin Điện Tử Đảng Bộ Thành Phố Hồ Chí Minh.

https://www.hcmcpv.org.vn/tin-tuc/van-dong-nguoi-lao-dong-tro-lai-doanh-nghiep-lamviec-trong-giai-doan-binh-thuong-moi-1491885693

XM. (2021). Dịch COVID-19 làm gia tăng tỷ lệ thất nghiệp và thiếu việc làm. Báo Tin Tức. https://baotintuc.vn/xa-hoi/dich-covid19-lam-gia-tang-ty-le-that-nghiep-va-thieu-viec-lam20210811121703967.htm 